\title{
FOREIGN IMMIGRATION \\ IN SPANISH RURAL AREAS AND SMALL TOWNS: CURRENT SITUATION AND PERSPECTIVES
}

\author{
RicARD MorÉn-Alegret ${ }^{1}$ \\ Miguel Solana ${ }^{1}$
}

\begin{abstract}
The authors are currently coordinating a three-year research project on the changing settlement patterns and ways of life of foreign immigrant populations located in Spanish rural areas. This article offers a wide academic literature review, highlighting those issues that have been most studied and those under-researched or forgotten. Secondly, it approaches the rural areas where there is a more significant presence of foreign immigrants, offering relevant data and indicating the main sources of information available for their study. Finally, some considerations that may be useful for carrying out future research are suggested.
\end{abstract}

Key words : Immigration in Spain, rural areas, employment sectors.

Resumo - IMIGRAÇÃo ESTRANGEIRA NAS ÁREAS RURAIS E NAS PEQUENAS CIDADES ESPANHOLAS: SITUAÇÃO ACTUAL E PERSPECTIVAS. Actualmente os autores estão a coordenar um projecto de investigação de três anos, sobre as mudanças nos padrões de distribuição geográfica e as formas de vida da população estrangeira nas áreas rurais espanholas. Neste artigo fazem uma revisão da bibliografia, sublinhando os temas mais estudados e aqueles que não foram ainda tratados ou são pouco conhecidos. Em seguida, fazem uma caracterização das áreas rurais com uma presença significativa de imigrantes estrangeiros, apresentam dados relevantes e indicam as principais fontes de informação disponíveis. Finalmente, tecem algumas considerações que podem ser úteis para futuras pesquisas.

Palavras-chave: Imigração em Espanha, áreas rurais, sectores de actividade.

I. FOREIGN MIGRATION INTO SPANISH RURAL AREAS AND SMALL

1 Migration Research Group, Department of Geography, Universitat Autònoma de Barcelona, 08193, Bellaterra (Barcelona), Spain. Tel. (+34) 935813067/(+34) 935811759. Fax (+34) 935812001. Email addresses: Ricard.Moren@uab.es, AntonioMiguel.Solana@uab.es. Web page: http://seneca. uab.es/migracions/index_en.html. 


\section{TOWNS: AN OVERVIEW}

Although throughout the last two decades most of the studies on international immigration in Spain have been focused on the arrival of foreign immigrants in metropolitan or large urban areas, a few authors have also paid attention to the situation of foreign immigrants beyond the cities' edges. Thus, as a first step of an extensive research project, we have been involved in research on the academic literature dealing with foreign migration into Spanish rural areas and small towns. The publications found can be grouped into three large thematic areas:

a) Working and residence conditions of foreign salaried workers in areas where agriculture is one of the key economic activities;

b) Social stratification processes affecting foreign workers in agriculture;

c) The relation of tourism and Northern European immigrants in coastal areas, mainly focusing on the factors that attract them, the process of social integration and the impact on the housing market.

In order to provide an overview, we offer a compilation of bibliographic references including the geographical areas mostly studied, the authors who have written on them and the main issues they have tackled so far in this section of the article.

Most authors have studied the working and residence conditions of foreign labourers in agriculture, linking them in some cases with 'integration' or segregation processes. A number of them have focused on specific rural areas ${ }^{2}$, with Andalusia being one of the most studied regions (See Figure 1). The most studied territory is the small town of El Ejido and other nearby areas in the Almeria province (Azurmendi, 2001; Castaño Madroñal, 2000, 2002; Chattou, 2000; Checa, 1995a, 1995b; Cózar Valero, 1993, 1994; Gómez LóPez, 1993, 1995; Martín Diaz et al., 1999; Pumares et al., 2000; Roquero, 1996; Ruíz, 1995; Sempere Souvannavong, 2001; Serrano Martinez, 1993). El Ejido and surrounding areas (Poniente almeriense) appeared in media headlines in early 2000 due to a social conflict involving Moroccan immigrant workers and other local residents. These areas are characterised by a very productive and lucrative intensive agriculture that is partially based on the intensive working conditions and low salaries of foreigners labouring under greenhouses made of plastic. Other Andalusian counties that have been studied are the olive orchards of Jaen (Martínez Chicón, 2002), the strawberry fields of Huelva and the Northwest coast of Cádiz (Cruces Roldán and Martín, 1997; Montaño Medina, 2002).

2 In this article, we do not consider the studies on foreign immigrants working in agriculture within metropolitan areas (for instance, a pioneering agricultural area in hosting immigrants like Maresme in the Barcelona Metropolitan Area is not taken into account here). 


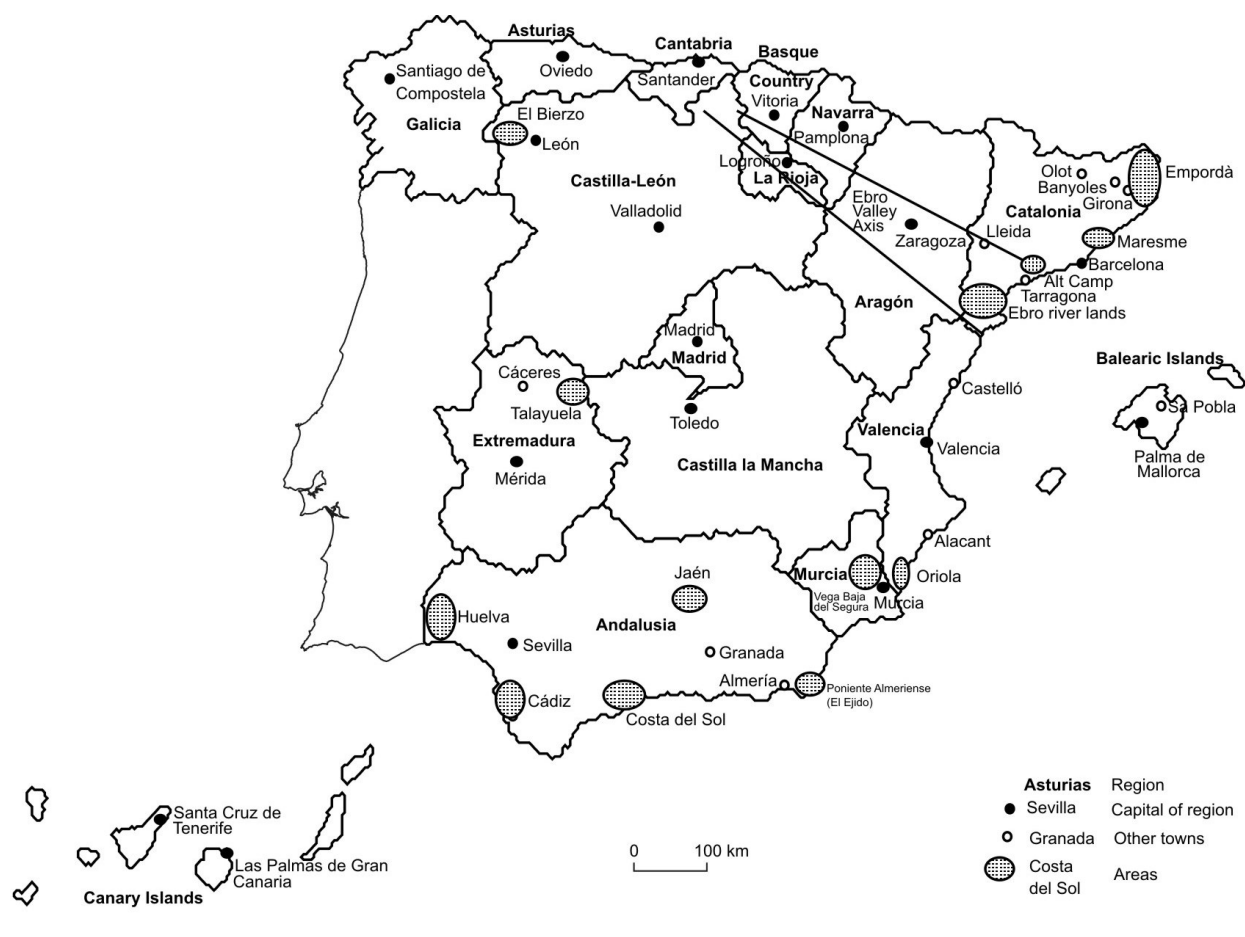

SOURCE: own elaboration.

Fig. 1 - Regional administrative division of Spain and location of the municipalities and areas quoted in this article.

Fig. 1 -Divisão administrativa regional de Espanha e localização das áreas e municípios referidos neste artigo.

In the countryside of Extremadura, Domingo Barbolla (2001) has studied the Talayuela area, in the province of Cáceres, a territory where foreign immigrants working in agriculture are relevant and where internal immigration from other parts of Extremadura was significant some decades ago. In his study, this author considers the tobacco plantations' labour demand as an attraction factor for Moroccan immigrants.

There are many studies as well on rural areas in Eastern Spain, like the agricultural fields worked by foreign immigrants in Murcia (BELTRÁN CAMPILlo and Miñano Martínez, 1996; Gómez Espín, 1995; Pedone, 2000; Pedreño CÁnovas, 1999; Sempere Souvannavong, 2001; Serrano Martínez, 1993) and in a few areas in the Valencia region, like the Castelló plain and the Oriola Valley (Avellá, 1991a, 1991b, 1992; Giménez, 1994; Jabardo Velasco, 1993; Viruela MarTínez, 1993). Among these studies, we highlight a couple of them because they deal with under-researched issues: the piece of work written by PEDONE (2000) is focused on international migrant workers networks and the article of 
PedReño CÁnovas (1999) examines the relations between the labour structure and the agro-industrial sector.

In Catalonia, the pioneering rural areas in hosting foreign immigrant workers were the Lleida plain (FUENTES BotARgues et al., 1988) and specific counties in the province of Girona, like La Selva (CRESPO and LÓPEZ, 1995) or Empordà (Hoggart and Mendoza, 1999; Mendoza, 1998). The Lleida province became a pioneer in establishing special triangular agreements between governments, workers' trade unions and agriculturalist employers associations for organising the labour contracts for African and South American immigrants during the harvest season. The province of Girona has become a reference in foreign immigration issues. In the late 1980s the first adults' school especially created for African immigrants in Spain was set up in Santa Coloma de Farners (the Samba Kubally school) and in 1992 a joint effort of several NGOs from diverse localities in Girona launched a Manifesto that was later used by the Catalan and Spanish governments in the making of the Immigrants Integration Plans (MORÉN-AlEgRET, 2002). More recently, it is the arrival of foreign labourers in the Ebro river valley of Southern Catalonia (Blanch Sedó, 2001; García Coll et al., 2002).

Other publications deal with working and residence conditions of foreign labourers in agriculture as well, but studying wider geographical areas as well as the Mediterranean side of Spain (Avellà and GarCía, 1995; BERLAN, 1987). Just a couple of authors have examined the arrival of foreign immigrants in agricultural areas of Spain as a whole, except for simply taking into account those who are temporary labourers in this case (GozÁLvez PÉREz and LóPEz TRIgal, 1999). Ubaldo MarTínez VeIga (1997) is one of the few academics having compared the working situation of foreign immigrants in a variety of agricultural areas (including rural and metropolitan ones) like El Ejido, El Maresme or La Vega Baixa del Segura, to the situation in a mining area like El Bierzo, and to the characteristics of a large metropolitan area like Madrid, where domestic services and the construction industry have been the usual sectors of employment.

Taking into account other aspects of foreign immigrants working in agriculture beyond the labour dynamics, there are a few studies on social stratification processes in rural areas. SuÁrez NAVAZ (1998) has analysed the impact of neo-liberal capitalist legislation and the subsequent police control in the stratification of local social relations in an agricultural valley in the province of Granada. IzCARA Palacios (2002) has studied how useful the concept of 'underclass' could be to understand both the increasing presence of foreign workers in Spanish agriculture and the still significant number of Spanish temporary agricultural labourers.

Even if today people living in rural areas work in a variety of economic sectors and not just in agriculture, there are just a few studies that have analysed foreign immigrants' involvement in other jobs outside of agriculture as well as their participation in daily life activities beyond the labour market. Thus, exceptional among the studies on Spanish rural areas is the work of Miquel NovaJRA 
(1996) who carried out an anthropological study of the Moroccan population in Sa Pobla, a village on the island of Majorca, in relation to the rest of the local society. His work included social intervention by a workers' trade union and the social services of the local government. More recently, FARJAS BONET (2002) has studied Gambian immigration in small towns like Banyoles and Olot (Girona), also paying attention to a variety of social issues.

On the other hand, publications linking tourism and foreign immigration from wealthier countries are relatively hard to find. Thus, the work of RAÚL Lardíes Bosque $(1999,2000)$ on the settlement of Northwestern European immigrants in Catalan tourist areas located beyond the Barcelona metropolitan region is exceptional as well. Other works on this kind of immigration have been focused on more urbanised areas like the Costa del Sol in Andalusia (BARKE and France, 1996; Betty and Cahill, 1998; Eaton, 1995; Rodríguez RodríGuez et al., 1998a, 1998b; NATERA Rivas, 1995; O’REILly, 1995), and the southern coast of Alicante (CASADo DíAZ, 1999, 2000). At the same time, other works have examined this issue, taking into account a wider geographical perspective (KING et al., 2000, 1998; KING et al., 1999; WARNES, 1991; WARNES et al., 1999; WiLliams et al., 1997).

In summary, there is a lack of studies willing to examine the whole picture of the foreign immigrants' labour market insertion in Spanish rural areas. Thus, in the next section of this article, we analyse relevant statistical data available in order to better understand what is currently occurring in these territories.

\section{TERRITORIAL DISTRIBUTION, SOURCES OF INFORMATION AND EMPLOYMENT OF FOREIGN IMMIGRANTS IN SPANISH RURAL AREAS AND SMALL TOWNS}

\section{The spatial presence of foreign immigrants in Spain}

Spain has had until recently one of the lowest levels of foreign presence when compared to other Western European countries. Since the 1980s, the percentage of foreigners has been increasing, especially during the 1990s, and in 2000 there was a quantitative leap. The more recent figure available (2002) places the percentage of foreigners at the highest level ever, $3.2 \%$. The total volume of foreign residents in Spain was 1,324,001, according to the data provided by the Dirección General de Policía ${ }^{3}$. This increase has been produced, in part, due to the results of the regularisation process undertaken between 2000-2001 and the recent reform of the Foreigners Law.

3 It includes Residence Permits for non-EU foreigners and Identity Cards for EU citizens (see www.idescat.es). 
A detailed spatial analysis displays the uneven concentration pattern of foreign immigrants in Spain (See Fig. 2). The maximum levels of concentration, both in relative and absolute numbers, are located in the following three areas:

a) The Mediterranean coast from the French border to Gibraltar. The Mediterranean shore includes the main Spanish tourist resorts (key points for the service and construction activities linked to tourism) that have attracted a diverse flow of immigrants looking, among other things, for some specific climate and housing conditions. This area also concentrates some of the most populated and economical dynamic areas in the country in terms of industry and commerce, such as Barcelona, Valencia, Alicante, Tarragona, etc. Some of the most intensive, productive and export-oriented agricultural areas of Spain can be found there, with the agro-industrial areas of Murcia and Almeria topping the list and, to a lesser extent, some areas in Catalonia and Valencia.

b) The Balearic and Canary Islands. They have some of the most dynamic labour markets in terms of capacity to create jobs in Spain but have constituted the main point of attraction for foreigners coming from the Northern and Western European countries - including retired people, businesspeople, young working students, - and so on, looking for some special climatic, environmental and social characteristics.

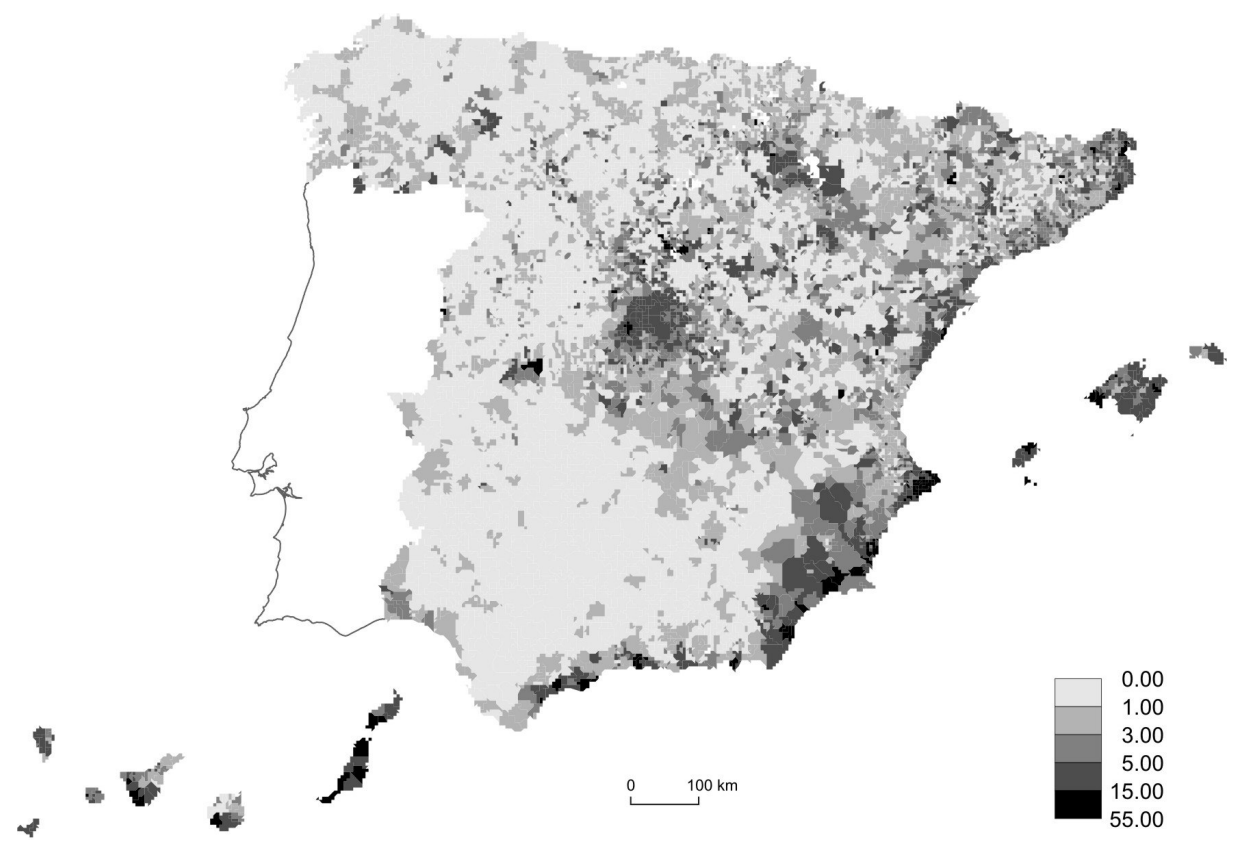

Fig. 2 - Percentage of foreigners at the municipality level, 2001.

Fig. 2 -Percentagem de estrangeiros por concelho, 2001. 
c) The metropolitan area of Madrid. The capital of Spain and its surrounding area is the most populated territory in the country.

d) The Ebro river valley. Wine production and a variety of fruit crops together with a growing industrial and services dynamism have attracted foreign immigrants to work in the Rioja-Navarra-Zaragoza-Lleida axis.

e) Finally, in some enclaves of intensive agriculture in Western and Southwestern Spain. In the strawberry fields in Huelva, the tobacco fields in Cáceres, as well as in the mining region of Leon, many African and Eastern European immigrants earn a living.

Consequently, the presence of foreign immigrants in non-metropolitan areas is quite significant. Another approach to the distribution of foreigners according to the settlement size is provided in Table 1. The main absolute volume of foreigners is concentrated in the main cities (more than 100,000 inhabitants), hosting almost half of the foreign population established in Spain in 2001. But if we compare the distribution of the total population and the

Table 1 - Distribution of foreign population (five main nationalities) according to size of settlement, 2001.

Quadro 1 - Distribuição da população estrangeira (cinco principais nacionalidades), por dimensão das localidades, 2001.

\begin{tabular}{lrrrrrrr}
\hline Volume & & & & & & United \\
& Population & Foreigners & Morocco & Ecuador & Colombia & Kingdom & Germany \\
\hline More than 100,000 inhab. & $16,451,485$ & 689,203 & 76,483 & 135,293 & 86,235 & 12,670 & 13,252 \\
50,000 to 100,000 inhab. & $4,231,284$ & 172,404 & 40,633 & 17,817 & 18,036 & 9,675 & 6,373 \\
25,000 to 50,000 inhab. & $4,101,219$ & 185,902 & 26,058 & 15,959 & 18,760 & 22,011 & 12,661 \\
10,000 to 25,000 inhab. & $6,411,972$ & 257,192 & 52,616 & 24,877 & 19,764 & 23,278 & 21,312 \\
5000 to 10,000 inhab. & $3,497,229$ & 120,140 & 23,446 & 10,843 & 7596 & 12,915 & 13,276 \\
2000 to 5000 inhab. & $3,160,725$ & 83,158 & 15,903 & 6793 & 5636 & 8341 & 6734 \\
1000 to 2000 inhab. & $1,424,139$ & 34,165 & 7727 & 2535 & 2178 & 2887 & 2345 \\
Less than 1000 inhab. & $1,569,318$ & 29,853 & 5006 & 2348 & 1891 & 3083 & 2064 \\
Total & $40,847,371$ & $1,572,017$ & 247,872 & 216,465 & 160,096 & 94,860 & 78,017 \\
Percentage & & & & & & & \\
More than 100,000 inhab. & 40.3 & 43.8 & 30.9 & 62.5 & 53.9 & 13.4 & 17.0 \\
50,000 to 100,000 inhab. & 10.4 & 11.0 & 16.4 & 8.2 & 11.3 & 10.2 & 8.2 \\
25,000 to 50,000 inhab. & 10.0 & 11.8 & 10.5 & 7.4 & 11.7 & 23.2 & 16.2 \\
10,000 to 25,000 inhab. & 15.7 & 16.4 & 21.2 & 11.5 & 12.3 & 24.5 & 27.3 \\
5000 to 10,000 inhab. & 8.6 & 7.6 & 9.5 & 5.0 & 4.7 & 13.6 & 17.0 \\
2000 to 5000 inhab. & 7.7 & 5.3 & 6.4 & 3.1 & 3.5 & 8.8 & 8.6 \\
1000 to 2000 inhab. & 3.5 & 2.2 & 3.1 & 1.2 & 1.4 & 3.0 & 3.0 \\
Less than 1000 inhab. & 3.8 & 1.9 & 2.0 & 1.1 & 1.2 & 3.3 & 2.6 \\
Total & 100.0 & 100.0 & 100.0 & 100.0 & 100.0 & 100.0 & 100.0 \\
\hline
\end{tabular}

Source: Instituto Nacional de Estadística, Census 2001. 
distribution of the foreign population, it is possible to see the parallelism between both columns of figures. Nevertheless, the smallest the towns are home the lowest levels of foreigners. This effect is produced by the dualism in the concentration of foreigners in municipalities with less than 10,000 inhabitants. This kind of municipality is one of the main destinations for foreign populations, but at the same time, in a high number of them, there is a low or absolutely no presence of foreigners. Another interesting factor that is possible to notice in the abovementioned table refers to different distribution patterns according to nationality. Foreigners from Great Britain and Germany - the main nationalities looking for a specific niche of the housing market in tourist resorts and rural areas - show a higher presence in the less populated municipalities than other nationalities, which are more concentrated in the country's main cities.

But if we focus our attention on the municipalities with a higher concentration of foreign populations, the results are quite interesting (Table 2). We have only considered the municipalities with more than $15 \%$ of foreign population over the total population (112 municipalities). Only eight of them have more than 25,000 inhabitants and, if we consider the official definition of 'urban area' in Spain (municipalities with more than 10,000 inhabitants), the number rises to 23 .

Table 2 - Distribution of foreign population according to the settlement size (only municipalities with a foreign population that comprises more than $15 \%$ of the total population), 2001.

Quadro 2 - Distribuição da população estrangeira por dimensão da localidade (incluindo apenas aquelas cuja população estrangeira representa mais de 15\% da população total), 2001.

\begin{tabular}{|c|c|c|c|c|}
\hline & Population & Foreigners & $\begin{array}{c}\text { Volume of } \\
\text { Municipalities }\end{array}$ & $\begin{array}{l}\text { Percentage of } \\
\text { foreigners in the } \\
\text { total population }\end{array}$ \\
\hline More than 25,000 inhab. & 336,342 & 72,123 & 8 & 21.4 \\
\hline 10,000 to 25,000 inhab. & 230,793 & 54,984 & 15 & 23.8 \\
\hline 5.000 to 10,000 inhab. & 132,424 & 34,886 & 18 & 26.3 \\
\hline 2000 to 5000 inhab. & 50,875 & 12,902 & 16 & 25.3 \\
\hline 1000 to 2000 inhab. & 16,916 & 4263 & 11 & 25.2 \\
\hline Less than 1000 inhab. & 17,163 & 4295 & 44 & 25.0 \\
\hline Total & 784,513 & 183,453 & 112 & 23.4 \\
\hline
\end{tabular}

Source: Instituto Nacional de Estadística, Census 2001.

In Spain, the municipalities with the highest rates of foreigners are mostly villages and small towns home to less than 10,000 inhabitants. These localities are mainly concentrated in the provinces of Alicante, Málaga, Las Palmas, Tenerife, Balearic Islands, Murcia and Almería. Thus the key area hosting the 
highest number of foreigners includes the territory all along the Mediterranean coastline and the islands, where a high concentration of tourism and intensive agriculture exist, and where there is a housing market addressed to Western European foreigners.

Our working hypothesis is that the economic dynamism of some Spanish rural areas is making them less dependent on agriculture. However, as it will be shown below, the available updated statistical data helps little in testing such a hypothesis.

\section{The statistical sources of information on foreign workers and labour market in the Spanish rural areas and small towns: problems and bias}

The statistical sources on foreign populations in Spain significantly underestimate the level and problems. These difficulties grow if we try to focus the study at the municipal level. The two statistical sources that provide specific information on foreign populations at this level for Spain as a whole are the Estadística de Permisos de Trabajo Concedidos a Extranjeros (Statistics of Labour Permits Granted to Foreigners) and Estadística de Afiliados Extranjeros en la Seguridad Social (Statistics of Foreign Workers Enrolled in Social Security). Both databases provide an annual record of the number of foreign workers in the Spanish labour market. However, as it is obvious, they hide an important group of foreigners with jobs in the informal economic sector. Furthermore, the statistical data on labour permits provides only information for non-EU foreigners, due to the fact that only they need a labour and residence permit. Thus it offers a partial picture of the foreign workers in the labour market.

The statistical data on enrolment in Social Security is more updated and the information provided is more accurate than the abovementioned statistics. However, its main problem is that it only offers data for Spain as a whole and at the provincial level, but not for the municipal level (See Table 3).

It is impossible to consider the structure and the incidence of foreigners in local labour markets, and we do not have a complete and accurate picture of rural labour markets and the insertion of foreign workers. Only the 2001 Census, which covers the whole range of municipalities, provides detailed information about the socio-demographic and occupational characteristics of the foreigners residing in the more than 8000 municipalities that comprise the Spanish local administrative division. Unfortunately, the great volume of data and the slow process of codifying and publishing this information makes access to it impossible at the moment.

Apart from the analysis of general statistical data offered by statewide agencies, there are other ways of knowing what are the main economic sectors in which foreign immigrants work in Spanish rural areas. One of them is by means of interviews with key informants, like trade union members active in these territories, and another one is consulting local surveys carried out by local institutions. 
Table 3 - Distribution of foreign workers in the Spanish labour market according to occupation (31/12/03).

Quadro 3-Distribuição sectorial dos trabalhadores estrangeiros no mercado de trabalho espanhol (31/12/2003).

\begin{tabular}{lccc}
\hline & Volume & Percentage & Percentage in total labour force \\
\hline Agriculture & 117,698 & 14.2 & 9.1 \\
Industry & 75,302 & 9.1 & 2.8 \\
Construction & 128,185 & 15.4 & 7.0 \\
Services & 510,033 & 61.3 & 4.9 \\
Unknown & 440 & 0.1 & 3.6 \\
& 831,658 & 100.0 & 5.2 \\
10 occupations with higher volume of foreign workers & & & \\
Construction & 128,185 & 15.4 & 7.0 \\
Hotels and restaurants & 121,057 & 14.6 & 9.5 \\
Agriculture & 117,698 & 14.2 & 4.1 \\
Business activities & 96,576 & 11.6 & 40.5 \\
Domestic service & 85,694 & 10.3 & 3.5 \\
Retail trade & 60,649 & 7.3 & 4.3 \\
Wholesale trade & 38,595 & 4.6 & 4.0 \\
Education & 19,848 & 2.4 & 4.2 \\
Cultural and social activities & 17,669 & 2.1 & 4.1 \\
Food industry & 14,626 & 1.8 & 2.3 \\
Other activities & 131,061 & 15.8 &
\end{tabular}

Source: Ministerio de Trabajo y Seguridad Social.

\section{Labour and immigration in a specific rural area: the case of Alt Camp County (Tarragona)}

According to Eduardo Moyano (1997, 2000), it is possible to distinguish between, on one hand, the self-employed farmers and employers' organisations (Coordinadora de Agricultores y Ganaderos (COAG), Asociación Agraria de Jóvenes Agricultores (ASAJA), and Unión de Pequeños Agricultores y Ganaderos (UPA) are the main ones in Spain on the whole) and, on the other hand, the salaried agricultural labourers' organisations that comprise a significant number of people in Andalusia and Extremadura alone (SOC, Comisiones Obreras del Campo and FTT are the main ones). The first group is composed both of medium and large landowners with a capitalist-oriented strategy mainly represented by the ASAJA (defenders of a vertical integration of production in agro-industrial complexes) on one hand and, on the other hand, small family farmers mainly represented by COAG and UPA (defending a horizontal integration of agriculture with other complementary activities like agro-tourism, environmental activities, etc.).

However, we can also increasingly locate the presence of several branches of the general trade union councils in rural areas (the main ones in Spain are 
Comisiones Obreras (CCOO) and Unión General de Trabajadores (UGT)). In this way, we can see again that agriculture is no longer the main source of employment in some rural areas. One such area is the county of Alt Camp, in the province of Tarragona. This territory is included in Leader+, a European Union program for rural development, but agriculture is no longer the main employer there. According to Carme Nuez (member of CCOO in Alt Camp) and Joan Gili (member of UGT in Alt Camp) ${ }^{4}$, there has been an expansion of industry and construction in this county and other areas of inland Catalonia, and a significant number of foreign immigrants have been attracted to these economic sectors.

In fact, Alt Camp County is also an area with its own County Plan for Immigrants' Integration (these kinds of plans are promoted by the Catalan government in some counties). One of the activities carried out by local institutions within the framework of this plan is a survey of foreign immigrants in order to analyse their integration. Therefore, in July 2001, members of a local foundation known as "Casa Caritat" interviewed over a hundred foreign immigrants, asking for personal data - family situation, degree of settlement, civic participation, labour situation, legal status and area of residence ${ }^{5}$. However, the sample only included persons from Northwest Africa (Morocco and Algeria), Latin America and Asia, the most common geographical origins among foreign immigrants in Alt Camp County.

If we focus on their labour situation (see Table 4), we find that a high number of immigrants work, although there is a significant number that do not answer this question, probably due to precariousness and the temporary jobs they can find.

Table 4 - Foreign immigrants' labour situation in Alt Camp, 2001.

Quadro 4-Situação perante o trabalho da população imigrante de Alt Camp, 2001.

\begin{tabular}{lrcr}
\hline Labour situation & Men & Women & Total \\
\hline Employed & 29 & 3 & 32 \\
Unemployed & 4 & 2 & 6 \\
Student & 8 & 5 & 13 \\
Homemaker & 0 & 27 & 27 \\
Do not know/No response & 22 & 7 & 29 \\
Total & 63 & 44 & 107 \\
\hline
\end{tabular}

Source: Pla Comarcal d'Integració dels Immigrants de l'Alt Camp, 178.

This table also suggests that many foreign immigrant women are not involved in the labour market and their contribution to the family activities is via home-

4 These interviews were made in fieldwork carried out in Alt Camp County from November 2002 to May 2003.

5 Among the variety of data offered by the Alt Camp's County Plan for Immigrants' Integration, there are tables in which the sample is composed of 107 individuals and other tables in which the sample is composed of 114 individuals. 
making. On the other hand, most men are active in the labour market and no one among them states that his main profession is homemaking.

Furthermore, if we analyse the economic activities where the involvement of foreign immigrants has been more common (see Table 5), it is possible to discern that agriculture is the sector hosting most individuals (41 of those interviewed). However, if we group together the number of foreign immigrants working in the industrial sector (17) and the building industry (23), the figure is almost the same (40 of those interviewed). The third sector, which includes hotels, domestic services and other services, hosted 33 persons.

Table 5 - Distribution of foreign immigrants per employment sector in Alt Camp, 2001.

Quadro 5 - Distribuição da população imigrante de Alt Camp por sector de actividade, 2001.

\begin{tabular}{lccc}
\hline Sector of Activity & Men & Women & Total \\
\hline Agriculture & 36 & 5 & 41 \\
Industry & 15 & 2 & 17 \\
Construction & 23 & 0 & 23 \\
Hotel services & 2 & 3 & 5 \\
Domestic services & 0 & 3 & 3 \\
Other services & 4 & 18 & 22 \\
Ambulant commerce & 2 & 1 & 3 \\
Total & 82 & 32 & 114 \\
\hline \multicolumn{2}{l}{ SourcE: Pla Comarcal d'Integració dels Immigrants de l'Alt Camp, 178. }
\end{tabular}

This data also illustrates a certain gender specialisation: agriculture, industry and construction are the sectors in which most foreign immigrant men are involved, while most women work in the service sector.

In summary, even if agriculture is still a key economic activity for foreign immigrants in some rural areas, in counties like Alt Camp today other economic sectors also attract a high number of foreign people.

\section{FINAL CONSIDERATIONS}

This article has offered an overview of the academic studies dealing with the arrival of foreign immigrants in Spanish rural areas, an analysis of the available statistical data that can shed some light on their distribution across the country and their economic activities, and an approach to their situation in a specific rural area. Thus the main objectives of the Spanish-wide research that we are coordinating at this moment are the study of issues related to these kinds of territories that have not been studied or are understudied and that would 
require special data gathering via fieldwork and specific research on the 2001 Population Census data. Some of the most relevant ones compiled are as follows:

a) Foreigner migration into rural areas is a complex issue. It is necessary to avoid considering agriculture as the unique sector of employment in which foreign immigrants residing in these areas work. In Spain, agriculture is a key economic sector that attracts foreign labourers, but it is not the only one. Tourism and other services, industry and construction are expanding sectors in some rural areas and small towns.

b) The relation between foreign immigrants and housing is becoming a crucial issue, especially in tourist areas. On the one hand, the arrival of Northern European immigrants may be raising housing prices and creating exclusive niches in which native people cannot afford living. On the other hand, some foreign workers from poorer countries may be forced to accept accommodation in very poor condition. This fact may contribute to making the improvement of social life in certain areas difficult.

c) The involvement of agricultural organisations, trade unions and other associations in the social integration and labour market insertion in rural areas is very relevant. Most studies on immigrants' associative issues have been focused on metropolitan contexts. Thus, it is useful to study the ambivalent position of certain rural residents both as workers and employers, and how they collectively defend their interests.

d) Governmental policies and social organisational processes related to the arrival of immigrant populations in rural areas (governance and immigration) should be examined. Among other questions to be explored, it has to be noted that since the early 1990s governmental policy on foreign immigration in Spain has been characterised, among other aspects, by the quota system. A significant part of the jobs offered through these quotas for foreign workers were specifically addressed to agriculture and domestic services, where labour offer and demand do not often match. It will be useful to explore to what extent the number of foreign workers included in these quotas are related to the needs expressed by local social agents, economic organisations and public institutions in rural areas.

e) Rural people's identity is affected by significant changes and the settlement of foreigners. At the same time, foreigners' identity is also affected by migration into a new land. In this sense, migration networks relating foreign people with Spanish urban and rural places have to be taken into account. Today it is especially crucial to unveil this identity game in order to facilitate their coexistence.

f) One of the key assets of rural areas is their landscape. Understanding how population changes are related to landscape transformations may contribute to a better organisation of the territory. This also includes the 
study of how diverse social groups daily relate with the natural surrounding local environment according to their geographical background.

g) Finally, as a transversal question, it is important to examine how the logics of social integration, systemic integration and habitat integration are affecting the rural population as a whole, including immigrants.

\section{REFERENCES}

Avellà, L. (dir.) (1991) - Necesidades de mano de obra en la recogida de naranja de la Comunidad Valenciana: estudio de la inmigración magrebi y condiciones de trabajo en el sector. Dirección General de Migraciones, Madrid.

Avellà, L. (1992) - La inmigración en la agricultura del País Valenciano. Dirección General de Migraciones/Conselleria de Treball de la Generalitat Valenciana, Valencia.

Avellà, L. L.; García, M. (1995) - La inmigración en las agriculturas mediterráneas. Revista Española de Economía Agraria, 172: 51-76.

Avellá Reus, L. (1991) - Los inmigrantes magrebíes en la recogida de cítricos de la Comunidad Valenciana. Revista de Treball, 17: 113-131.

Azurmendi, M. (2001) - Estampas de El Ejido: un reportaje sobre la integración del inmigrante. Taurus, Madrid.

Barbolla, D. (2001) - Sobre los trabajadores inmigrantes en el cultivo del tabaco en Talayuela, Cáceres. Facultad de Ciencias Económicas y Empresariales, Universidad de Extremadura.

Barke, M.; France, L. A. (1996) - The Costa del Sol. In M. Barke et al. (eds.)-Tourism in Spain. Critical issues. CAB Internacional, Newcastle.

Beltrán Campillo, F.; Miñano Martínez, J. (dir.) (1996) - Censo y caracterización de las viviendas usadas por inmigrantes en la región de Múrcia 1996. Asociación Columbares/Dirección General de Migraciones, Murcia/Madrid.

BerLan, J. P. (1987) - La agricultura 'mediterránea' y el mercado de trabajo: ¿Una California para Europa? Agricultura y Sociedad, 42: 233-245.

BetTy, C.; CAHILL, M. (1998) - Consideraciones sociales y sanitarias sobre los inmigrantes británicos mayores en España, en particular los de la Costa del Sol. Migraciones, 3: 83-115.

Blanch Sedó, C. (2001) - La producció de cítrics a Alcanar: el paper de la mà d'obra immigrada magribina i la 'nova immigració'. Scripta Nova, 94.

CAmarero, L. A. (1993) - Del éxodo rural y del éxodo urbano. (Ocaso y renacimiento de los asentamientos rurales en España). Ministerio de Agricultura, Pesca y Alimentación, Madrid.

Casado Diaz, M. Á. (1999) - Socio-demographic Impacts of Residential Tourism: a Case Study of Torrevieja, Spain. International Journal of Tourism Research, 1: 223-237.

CASADo DiAZ, M. Á. (2000) - De turistas a residentes: inmigrantes retirados europeos en Torrevieja, Costa Blanca. Presented at II Congreso Internacional sobre la Inmigración en España, España y las migraciones internacionales en el cambio de siglo. Universidad Pontificia de Comillas, Madrid.

CASTAÑo Madroñal, A. (2000) - Una sociedad ahogada en un "mar de plásticos": factores precipitantes de una persecución étnica. Presented at II Congreso de la Inmigración en España. Universidad Pontificia de Comillas, Madrid. 
CASTAÑo MAdRoñal, A. (2002) - Vivienda, residencialidad y construcción del espacio. La segregación espacial de los inmigrantes marroquíes en el Ejido y sus efectos sociales. Presented at III Congreso sobre la inmigración en España. Universidad de Granada, Granada.

Cebrián, J. A.; Bodega, M. I.; López-Sala, A. M. (2000) - La presencia africana en la inmigración española del cambio de siglo. Estudios Geográficos, 240: 435-460.

Chattou, Z. (2000) - Los trabajadores agrícolas marroquíes de El Ejido. De la invisibilidad a la toma de conciencia de si mismos. Migraciones, 8: 203-229.

CHECA, F. (1994) - Invernaderos e inmigrantes: el problema de la adaptación de un colectivo marginal. Dirección General de Migraciones, Madrid.

CHECA, F. (1995a) - Oportunidades socioeconómicas en el proceso migratorio de los inmigrantes africanos en Almería. Agricultura y Sociedad, 77: 41-82.

CHECA, F. (1995b) - Del riesgo de las pateras a la supervivencia en los invernaderos. Inmigrantes en la provincia de Almería. Revista de Economía y Sociología del Trabajo, 29-30: 41-82.

CHECA, F. (1996) - Invernaderos e inmigrantes: el problema de la adaptación de un colectivo marginal. Dirección General de Migraciones (2. ${ }^{\mathrm{a}}$ parte) , Madrid.

CózAr VAlero, M. E. (1993) - Almería: de la emigración a la inmigración. Consecuencias demográficas y territoriales. In GARCíA, J. L. Z.; ZAPATA, V. M.; MilláN, P. M. (eds.) - Inmigración extranjera y planificación demográfica en España. Universidad de la Laguna, Tenerife: 557-562.

Cózar Valero, M. E. (1994) - La inmigración africana en Almería. Presented at Simposio Internacional sobre Desertización y Migraciones. ONU, Almería.

CRESPO, R.; LóPEZ, M. (1995) - Estudio diagnóstico de las minorías étnicas en la comarca de La Selva, 1994-1995. Dirección General de Migraciones, Madrid.

CRuces RoldÁN, C.; MarTín, E. (1997) - Intensificación agraria y transformaciones socioculturales en Andalucía Occidental. Análisis comparado de la Costa Noroeste de Cádiz y el condado Litoral de Huelva. Sociología del Trabajo, 30 (Nueva Época).

EATon, M. (1995) - British expatriate service provision in Spain's Costa del Sol. Services industries Journal, 15: 251-266.

EscandelL, V. (1993) - El impacto de la inmigración extranjera en pequeños municipios: dos ejemplos diferentes en la España mediterránea. In García, J. L. Z.; ZAPATA, V. M.; Millán, P. M. (eds.) - Inmigración extranjera y planificación demográfica en España. Universidad de la Laguna, Tenerife: 533-539.

FARJAS Bonet, A. (2002) - El proceso migratorio gambiano en la provincia de Girona. Presented at III Congreso sobre la inmigración en España. Universidad de Granada, Granada.

FERNÁNDEZ CAVADA, J. L. (1994) - La población activa agraria y la participación de inmigrantes en el mercado de trabajo agrario. Papeles de Economía Española, 60-61: 156-165.

Fuentes Botargues, A. A.; Cansino Fernández, M.; Echeverría Cortada, L. (Equipo de Población y Derechos Civiles) (1988) - Estudio de la población inmigrante africana de raza negra que vive permanentemente en Lérida y provincia. Gobierno Civil de Lérida, Lleida.

García COLL, A. et al. (2002) - La inmigración en las comarcas del Ebro: nuevas poblaciones para viejas estructuras. Presented at III Congreso sobre la inmigración en España. Universidad de Granada, Granada.

GIMÉNEz, C. (1994) - Magrebíes, agricultura y marginación en el litoral valenciano. In VVAA (1994) (ed.). Agriculturas mediterráneas y mundo campesino. Instituto de Estudios Almerienses y Diputación de Almería, Almería.

Gimenez Romero, C. (1992) - Trabajadores extranjeros en la agricultura española, enclaves e implicaciones. Estudios Regionales, 31: 121-147. 
Gómez Espín, J. M. (1995) - Las transformaciones agrarias murcianas o el paso de una agricultura tradicional a otra comercial. Su incidencia sobre la inmigración magrebí. In VILAR, J. B. (ed.) - Murcia, frontera demográfica en el sur de Europa. Secretariado de Publicaciones de la Universidad de Murcia, Murcia.

Gómez López, J. D.; Segrelles Serrano, J. A. (1993) - La situación de la mano de obra marroquí en los invernaderos del Campo de Dalías (Almería). In García, J. L. Z.; ZaPATA, V. M.; MilláN, P. M. (eds.) - Inmigración extranjera y planificación demográfica en España. Universidad de la Laguna, Tenerife: 563-568.

Gómez López, J. D.; Segrelles Serrano, J. A. (1995) - Agricultura intensiva y mano de obra marroquí en el Campo de Dalías (Almería). Boletín del Instituto de Estudios Almerienses, 14: 155172.

GozÁlvez PÉRez, V.; LóPez Trigal, L. (1999) - Jornaleros extranjeros en el campo español. Ería, 49: 213-229.

Hoggart, K.; Mendoza, C. (1999) - African immigrant workers in Spanish agriculture. Sociologia Ruralis, 4: 538-562.

Izcara Palacios, S. P. (2002) - Infraclases rurales: procesos emergentes de exclusión social en España. REIS, 97: 127-154.

Jabardo Velasco, M. (1993) - Inmigrantes magrebíes en la agricultura: la Vega Baja del Segura (Orihuela). In B. López (ed.) - Inmigración magrebí en España. El retorno de los moriscos. MAPFRE, Madrid: 267-288.

King, R.; Patterson, G. et al. (1999) - The well-being of British expatriate retirees in southern Europe. Ageing and Society, 19(6): 717-740.

KING, R.; WARNES, A.M. et al. (1998) - International Retirement Migration in Europe. International Journal of Population Geography, 4: 91-111.

KING, R.; WaRnES, A. M. et al. (2000) - Sunset lives: British retirement migration to the Mediterranean. Berg, Oxford

LARDíEs Bosque, R. (1999) - Turismo e inmigrantes extranjeros de origen comunitario: el desarrollo de empresas turísticas en el litoral catalán. Geographicalia, 37: 87-104.

LARdíEs Bosque, R. (2000) - Inmigrantes comunitarios y desarrollo de empresas turísticas en las zonas costeras de Cataluña. Ería, 53: 271-285.

Martín Diaz, E.; Castaño, A.; Rodríguez, M. (1999) - Procesos migratorios y relaciones inter-étnicas en Andalucía: una reflexión sobre el caso del Poniente almeriense desde la Antro-pología social. OPI, Ministerio de Trabajo y Asuntos Sociales; Consejería de Asuntos Sociales de la Junta de Andalucía, Madrid.

MARTínez Chicón, R. (2002) - Contradicciones y concordancias en la atracción y expulsión de trabajadores asalariados en el mercado laboral del olivar. La incorporación de extranjeros. Presented at III Congreso sobre la inmigración en España. Universidad de Granada, Granada.

MARTínez VeIgA, U. (1997) - La integración social de los inmigrantes extranjeros en España. Trotta, Madrid.

MendozA, C. (1998) - African Employment in Iberian Agriculture and Construction: a Cross-border Comparative Approach. Ph.D. Thesis, Department of Geography, King's College, University of London, London.

Miquel Novajra, A. (1996) - Un soc al pla. Una aproximació a la població magribí de Sa Pobla (Mallorca). Palma de Mallorca: Comissions Obreres de les Illes Balears/Conselleria de Treball i Formació del Govern Balear.

Montaño Medina, J. (2002) - Inmigración e infravivienda en el condado litoral onubense. Apuntes para una investigación. Presented at III Congreso sobre la inmigración en España. Universidad de Granada, Granada. 
MoréN-Alegret, R. (2002) - Integration and Resistance. The relation of social organisations, global capital, governments and international immigration in Spain and Portugal. Ashgate Publishers, Aldershot, UK.

Moyano, E. (1997) - Acción colectiva y sindicalismo agrario en España. In Gómez Benito, C.; GonzÁlez Rodríguez, J. J. (eds.). Agricultura y Sociedad en la España contemporánea. Siglo XXI, Madrid.

Moyano, E. (2000) - Procesos de cambio en la sociedad rural española. Pluralidad de intereses en una nueva estructura de oportunidades. Papers, 61: 191-220.

Natera Rivas, J. J. (1995) - Transformaciones recientes en la población de piedemonte de la Costa del Sol occidental debidas al turismo. Habitar, vivir, prever. Actas del V Congreso de Población Española. UAB, Bellaterra: 499-504.

O'REILLY, K. (1995) - A new trend in European migration: contemporary British migration to Fuengirola, Costa del Sol. Geographical Viewpoint, 23: 25-36.

Paniagua, A. (2000) - Migrantes, líderes y restructuración rural en áreas desfavorecidas del interior. Un caso de estudio. In Actas del X Coloquio de Geografía Rural.

Pedone, C. (2000) - Globalización y migraciones internacionales: cadenas y redes migratorias de trabajadores ecuatorianos en Murcia. Departament de Geografia, Universitat Autònoma de Barcelona, Bellaterra.

Pedreño Cánovas, A. (1999) - Construyendo la 'huerta de Europa': Trabajadores sin ciudadanía y nómadas permanentes en la agricultura murciana. Migraciones, 5: 87-120.

Ponce Herrero, G.; Valero Escandell, J. R.; Palazón Ferrando, S. (1996) - Marroquíes en Cataluña. Estrategias selectivas de integración: la gran ciudad, los núcleos industriales y los municipios menores. Boletín de la AGE, 23: 151-167.

Pumares, P. et al. (2000) - El futuro del Poniente Almeriense: situación, actitudes y perspectivas tras los acontecimientos de febrero de 2000. Presented at II Congreso de la Inmigración en España. Universidad Pontificia de Comillas, Madrid.

Rodríguez Rodríguez, V. et al. (1998a) - European Retirees on the Costa del Sol: A Cross-National Comparison. International Journal of Population Geography, 4: 183-200.

Rodríguez RodríGuez, V. et al. (1998b) - Los inmigrantes europeos jubilados en Andalucía. Rasgos sociodemográficos, motivaciones para migrar y modo de vida. IEA, Sevilla.

Roquero, E. (1996) - Asalariados africanos trabajando bajo plástico. Un caso de segregación en el Poniente de Almería. Sociología del Trabajo, 28: 3-23.

Ruíz, P. (1995) - Inmigración y mercado laboral en la horticultura forzada almeriense. Una aproximación. Demófilo, 15: 135-155.

Santana Afonso, A. I. (1995) - La mano de obra marroquí en el sector agrícola. Dirección General de Migraciones, Madrid.

Santos Lozano, M. (1995) - Temporerismo agrícola en España. Programa de Inmigrantes y Rural, Cáritas Española, Madrid.

Sempere Souvannavong, J. D. (2001) - Latinoamericanos y magrebíes en el medio rural. Las provincias levantinas. Scripta Nova, 94.

Serrano Martínez, J. M. (1993) - Inmigración de carácter laboral en la región de Murcia procedente de los países del Magreb al inicio de los años noventa. In GARCíA, J. L. Z.; ZAPATA, V. M. Millán, P. M. (eds.) - Inmigración extranjera y planificación demográfica en España. Universidad de la Laguna, Tenerife: 569-576.

SuÁREZ NAVAZ, L. (1998) - Dinámicas y políticas de invisibilidad. Ley, vigilancia y racialización en la agricultura. Migraciones, 4: 177-214. 
Viruela Martínez, R. (1993) - Condiciones de vida y trabajo de los magrebíes en España: marroquíes en la provincia de Castelló. In García, J. L. Z.; Zapata, V. M.; Millán, P. M. (eds.) - Inmigración extranjera y planificación demográfica en España. Universidad de la Laguna, Tenerife: 547-556.

WARNES, A. M. (1991) - Migration to and seasonal residence in Spain of Northern European elderly people. European Journal of Gerontology, 1(1): 53-60.

WARnes, A. M.; KING, R. et al. (1999) - The well-being of British expatriate retirees in southern Europe. Ageing and Society, 19: 717-740.

Williams, A. M.; KING, R. et al. (1997) - A place in the sun: international retirement migration from Northern to Southern Europe. European Urban and Regional Studies, 4: 115-134. 